\title{
Carboniferous and Triassic conodonts from Syrian boreholes
}

\author{
SAMIRA HUSRI \& RONALD L. AUSTIN \\ Department of Geology, The University, Damascus, Syria \& Department of Geology, The University, Southampton, Hants.
}

\begin{abstract}
A sparse but important collection of conodonts recovered from four boreholes in north-eastern and central Syria contains Neogondolella mombergensis, which is the first record of Triassic conodonts from Syria. The Carboniferous rocks are characterised by species of Gnathodus which indicate the presence of late Tournaisian to late Viséan strata.
\end{abstract}

\section{THE CARBONIFEROUS OF SYRIA}

Prior to 1960, knowledge of the Carboniferous rocks of Syria was very limited partly because strata of this age are poorly exposed. The earliest reference to the Carboniferous rocks of Syria was by Dubortret (1932), who reported the occurrence of Lower Carboniferous strata in the Abd-Al-Aziz mountain region. Later Weber (1964), Wolfart (1967) and Ponikarov (1969) described the deposits of the Carboniferous System in Syria. Yankauskas (1976), with the help of geologists from the Syrian Petroleum Company, studied the microfossils of the Palaeozoic formations, which had been penetrated at depth in different parts of Syria. Acritarchs in particular were used to determine the geological age of these deposits. Stoppel (1970), reported the occurrence of conodonts in Lower Carboniferous rocks outcropping in the Abd-Al-Aziz mountain. This is the only previously published record of conodonts in Syria.

The only outcrop of Tournaisian rocks in the whole of Syria occurs in the Abd-Al-Aziz anticline, within the Twal-el-Aba-Sinjar rampart. It consists of $21 \mathrm{~m}$ of thinly stratified marine shale, with intercalations of sandstone and limestone. The rocks occur as a fault-bounded block forming a dismembered unit surrounded by Cretaceous beds. They are fossiliferous containing the brachiopods Chonetes sp., Laguessianus sp., Spirifer aff. S. tournacensis and Buxtonia scabricula. The exact nature of the outcrop is not certain, but it is most probable that the Carboniferous represents an exotic block, or an upthrown block within Cretaceous rocks.

In other parts of Syria, the Carboniferous deposits are unexposed being overlain by a thick sedimentary cover of deposits of Mesozoic-Cenozoic age. Consequently, a number of deep boreholes have been drilled in different areas to enable the buried formations to be studied. Study of the borehole data has established that marine Lower Carboniferous deposits occur at depth over most of Syria with a thickness of up to $1100 \mathrm{~m}$ in the northeastern part (in the Markada Borehole - 101). They become thinner towards the central part, being about $338 \mathrm{~m}$ in the Dalaa Borehole and $310 \mathrm{~m}$ in the Doubayat Borehole. Lower Carboniferous deposits are absent from the extreme southern portion of the country. The deposits show regional variations in facies. In the southern and central part of Syria (in the Tenf and Swab Boreholes), they are represented by sandstones, intercalated with grey argillites and cream coloured dolomites with fragments of coal and fossil wood. These rest unconformably on Silurian rocks at Tenf and on Ordovician rocks at Swab. They are overlain unconformably by carbonates of Upper Cretaceous age. In the northeast of Syria (in the Markada - 101 and El-Bowab Boreholes) the Lower Carboniferous is represented by massive, black, schistose, argillites with intercations of dolomite, which rest unconformably on Silurian rocks at Markada and on Ordovician rocks at El-Bowab. They are overlain unconformably by Triassic deposits. Wolfart (1967) found spores in the boreholes at El-Bowab and AlBarde, which indicated that the Lower Carboniferous is conformably overlain by rocks of Upper Carboniferous (Stephanian - Westphalian and Namurian) age.

\section{THE LOCATION OF THE BOREHOLES AND SAMPLES PROCESSED FOR CONODONTS}

Samples from boreholes at four selected localities in north-eastern and central Syria (Fig. 1) were studied in an attempt to establish a biostratigraphic zonation utilising conodonts.

The boreholes studied were those of Swab-1, Markada -101 , Jbissa-207 and Roumylan-6. The numbering system follows that employed by the Syrian Petroleum Company.

I - THE SWAB BOREHOLE Swab is located to the south of the city of Dier-Al-Zor. Four cores were taken from different horizons at the depths indicated. The samples studied were as follows:- 
Core 5: $\quad 1251.85 \mathrm{~m} \quad$ Light grey siltstone with very

$(0.9 \mathrm{Kg})$

Core 6:

$1296.80 \mathrm{~m}$

$(5.2 \mathrm{Kg})$

$1297.60 \mathrm{~m}$

$1298.70 \mathrm{~m}$

$1299.80 \mathrm{~m}$

$1330.30 \mathrm{~m}$

Core 7: $\quad 1379.95 \mathrm{~m}$

$(5.05 \mathrm{Kg}) 1380.90 \mathrm{~m}$ Light grey microcrystalline

Dark grey, thin laminated fossiliferous shale.

Dark grey, coarse, crystalline dolomite intercalated with dark grey laminated shale, containing conodonts.

Dark grey, coarse, crystalline dolomite, with pure crystalline barite.
$1382.90 \mathrm{~m}$ $1384.65 \mathrm{~m}$ $1386.80 \mathrm{~m}$ $1383.75 \mathrm{~m}$

Core 8: $(3.25 \mathrm{Kg})$

$1491.85 \mathrm{~m}$ $1496.80 \mathrm{~m}$ $1493.70 \mathrm{~m}$

$1498.75 \mathrm{~m}$ sandstone cemented by dolomite.

Light grey sandstone cemented by silicified material, interbedded with very thin beds of black micaceous shale.

White sandstones with siliceous cement.

Light grey sandstone intercalated with thin streaks of micaceous shale.

Dark grey laminated shale.

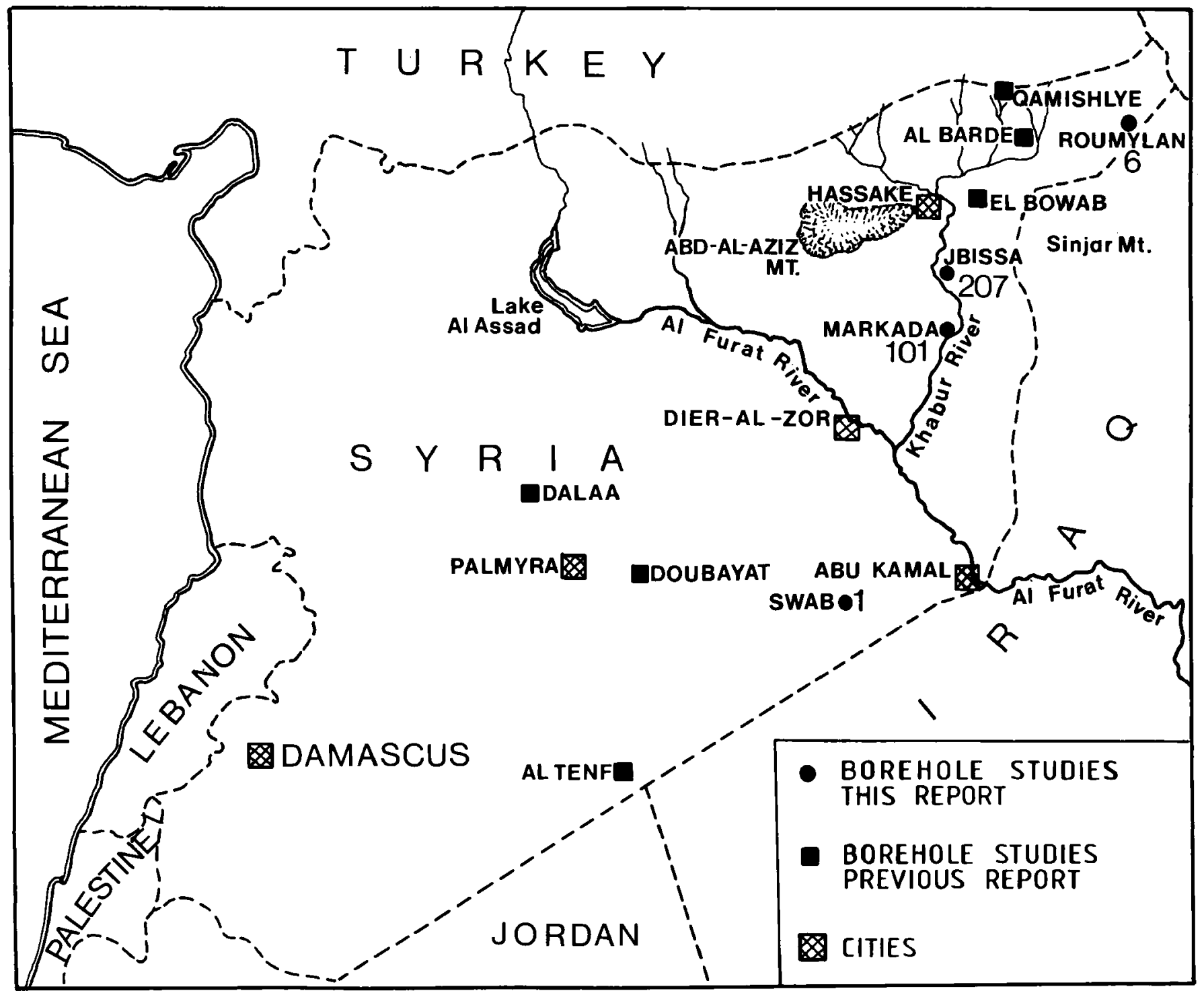

Fig. 1. Locality map showing sites of boreholes. 
II - THE MARKADA BOREHOLE-101 Markada is situated on the east bank of Khabur River. Four cores were taken from different horizons at the depths indicated. The following samples were studied:-

Core 18: $3117.80 \mathrm{~m}$ Dark grey microcrystalline $(5.9 \mathrm{Kg}) \quad 3120.30 \mathrm{~m}$ dolomite, intercalated with

$3122.45 \mathrm{~m}$ streaks of dark grey laminated shale. The dolomite partly fractured, the fractures filled with calcite.

$3123.80 \mathrm{~m}$ Red brown, sandstone, $3125.10 \mathrm{~m}$ cemented by ferruginous material.

Core 19: $\quad 3361.90 \mathrm{~m} \quad$ Black laminated shale contain$(2.8 \mathrm{Kg}) \quad 3362.60 \mathrm{~m}$ ing foraminifera, spores and $3363.80 \mathrm{~m}$ conodonts.

Core 20: $3428.95 \mathrm{~m}$ Dark grey, microcrystalline $(3.5 \mathrm{Kg}) \quad 3429.85 \mathrm{~m}$ limestone, interbedded with thin, black fossiliferous shale.

$3435.90 \mathrm{~m}$ Dark grey, fossiliferous, micro$3436.40 \mathrm{~m}$ crystalline limestone.

Core 21: $\quad 3752.70 \mathrm{~m} \quad$ Light grey sandstone cemented $(2.5 \mathrm{Kg}) \quad 3753.90 \mathrm{~m}$ by silicified material, inter$3755.80 \mathrm{~m}$ bedded with thin beds of black, $3757.60 \mathrm{~m}$ micaceous shale.

III - THE JBISSA BOREHOLE-207 Jbissa is situated $40 \mathrm{~km}$ to the North of the Markada structure. The following samples were taken at the depths indicated:-

Core 1: $\quad 3867.80 \mathrm{~m}$ Dark grey sandstone inter$(2.2 \mathrm{Kg}) \quad 3869.40 \mathrm{~m}$ bedded with black, laminated micaeous shale.

Core 2: $3936.90 \mathrm{~m}$ Black laminated shale with $(2.2 \mathrm{Kg}) \quad 3838.70 \mathrm{~m}$ streaks of grey dolomite.

$3939.60 \mathrm{~m}$ Green laminated shale.

Core 3: $\quad 4146.30 \mathrm{~m}$ Dark grey, microcrystalline $(3.9 \mathrm{Kg}) \quad$ limestone, which is fractured, the fractures being filled with calcite and barite.

$4147.80 \mathrm{~m}$ Black laminated fossiliferous shale.

$4149.85 \mathrm{~m}$ Dark grey, microcrystalline limestone.

Core 4: $\quad 4178.90 \mathrm{~m}$ Black microcrystalline lime$(3.7 \mathrm{Kg}) \quad$ stone containing conodonts. $4180.80 \mathrm{~m}$ Black shale.

Core 5: $\quad 4252.75 \mathrm{~m} \quad$ Black laminated shale.
IV - THE ROUMYLAN BOREHOLE-6 Roumylan is situated to the North-east of Syria. The samples were collected from four cores drilled at different depths. The following samples were processed:-

Core 17: Samples from the intervals $3578-3589 \mathrm{~m}$ $(2.5 \mathrm{Kg}) \quad$ were light grey sandstone intercalated with very thin laminated grey shale.

Core 18: Samples from the interval $3589-3593.50 \mathrm{~m}$ $(4.7 \mathrm{Kg})$ consist of black shale with dolomite and barite.

Core 19: A sample was taken from the interval 3602 $(0.9 \mathrm{Kg}) \quad 3604 \mathrm{~m}$. It was a dark grey limestone with shale.

Core 20: Samples of black limestone and laminated $(3.5 \mathrm{Kg}) \quad$ shale were collected from the interval 3618 $-3629 \mathrm{~m}$. They contained brachiopods.

Core 21: Dark grey, compact, highly argillaceous $(1.0 \mathrm{Kg})$ limestone with some veins of quartz.

\section{THE CONODONT FAUNA}

The present study is based upon 55 rock samples, each approximately one kilogram in weight, which were collected from the mainly Lower Carboniferous deposits present in four boreholes in north-eastern and central Syria. Eleven samples contained conodonts. The conodonts were not very abundant and generally occurred as fragments. The Carboniferous fauna is dominated by the genus Gnathodus. The numerical distribution of the conodont elements recovered is illustrated (Figs. 2-4).

\section{THE SWAB BOREHOLE: (Fig. 2)}

Samples from Cores 5, 7 and 8 failed to yield any conodonts. Samples from Core 6 yielded elements representing 16 species and 7 genera. The composition of the fauna changes through the depth interval $1296.60 \mathrm{~m}$ to $1300.30 \mathrm{~m}$. The species Gnathodus bilineatus and Gnathodus girtyi girtyi are present at the top and Gnathodus pseudosemiglaber characterises the lower interval. Gnathodus cuneiformis and Gnathodus homopunctatus are found only at a depth of $1297.60 \mathrm{~m}$. Samples from the depth range $1297.60-1298.70 \mathrm{~m}$ produced Gnathodus texanus. A single specimen of Gnathodus symmutatus symmutatus occurs at a depth of $1298.70 \mathrm{~m}$.

The occurrence of the species Gnathodus bilineatus, Gnathodus girtyi, Gnathodus cuneiformis, Gnathodus texanus and Gnathodus pseudosemiglaber in samples from the Swab Borehole allows approximate correlation to be made with the Lower Carboniferous conodont zones recognised in western Europe. The appearance of the species $G$. bilineatus and $G$. girtyi at a depth of $1296.80 \mathrm{~m}$. is of considerable importance as they are the 


\begin{tabular}{|c|c|c|c|c|c|}
\hline \multirow{3}{*}{$\begin{array}{l}\text { DEPTH IN BOREHOLE (METRES) } \\
\text { CONODONTS }\end{array}$} & \multicolumn{2}{|c|}{ SWAB } & \multicolumn{3}{|c|}{ BOREHOLE } \\
\hline & \multicolumn{5}{|c|}{ CDRE 6} \\
\hline & $1296 \cdot 80$ & $1297 \cdot 60$ & $1298 \cdot 70$ & $1299 \cdot 80$ & $1300 \cdot 30$ \\
\hline \multirow{9}{*}{$\begin{array}{l}\text { Euprioniodina microdentata } \\
\text { Euprioniodina sp. } \\
\text { Gnathodus bilineatus } \\
\text { Gnathodus girtyi girtyi } \\
\text { Gnathodus cuneiformis } \\
\text { Gnathodus homopunctatus } \\
\text { Gnathodus symmutatus symmutatus } \\
\text { Gnathodus pseudosemiglaber } \\
\text { Gnathodus texanus }\end{array}$} & & 1 & & & \\
\hline & & & & & \\
\hline & 2 & & & & \\
\hline & 4 & & & & \\
\hline & & 3 & & & \\
\hline & & & & & \\
\hline & & & 1 & & \\
\hline & & 13 & 4 & 1 & 1 \\
\hline & 4 & 2 & & & \\
\hline \multirow{7}{*}{$\begin{array}{l}\text { Hindeodella ibergensis } \\
\text { Hindeodella sp. } \\
\text { Ligonodina roundyi } \\
\text { Lonchodina furnishl } \\
\text { Lonchodina sp. } \\
\text { Neoprioniodus sp. } \\
\text { Ozarkodina plana } \\
\text { Fragments }\end{array}$} & $\frac{4}{1}$ & & 2 & & \\
\hline & & 1 & & & \\
\hline & 3 & 2 & & & \\
\hline & & 2 & 2 & 1 & \\
\hline & & 1 & & & \\
\hline & & & 1 & & \\
\hline & 4 & 1 & 13 & 2 & 4 \\
\hline
\end{tabular}

Fig. 2. Conodont species, Swab Borehole.

\begin{tabular}{|c|c|c|c|c|c|c|c|c|}
\hline \multirow{3}{*}{$\begin{array}{l}\text { DEPTH IN BOREHOLE (ME RES) } \\
\text { CONO D ONTS }\end{array}$} & \multicolumn{8}{|c|}{ MARKADA BOREHOLE } \\
\hline & CORE 18 & \multicolumn{3}{|c|}{ CORE 19} & \multicolumn{4}{|c|}{ CORE 20} \\
\hline & $3120 \cdot 30$ & $3361 \cdot 90$ & $3362 \cdot 60$ & 3363.80 & 3428.95 & 3429.85 & 3435.90 & 3436.40 \\
\hline \multirow{11}{*}{$\begin{array}{l}\text { Apatognathus geminus } \\
\text { Apatognathus sp. } \\
\text { Gnathodus cuneiformis } \\
\text { Gnathodus pseudosemiglaber } \\
\text { Gnathodus texanus } \\
\text { Lonchodina furnishi } \\
\text { Lonchodina sp. } \\
\text { Neogondolella mombergensis } \\
\text { Neoprioniodus scitulus } \\
\text { Neoprioniodus sp. } \\
\text { Spathognathodus scitulus } \\
\text { Genus sp. indeterminate } \\
\text { Fragments }\end{array}$} & & & & & & & 2 & \\
\hline & & & & & & & 1 & \\
\hline & & & 1 & & 2 & & & \\
\hline & & & & 1 & 4 & 5 & 1 & 1 \\
\hline & & & 1 & & & 1 & & 1 \\
\hline & & & & & & & & 2 \\
\hline & 2 & & & & 1 & 1 & & \\
\hline & & & & & 1 & & $\mathrm{~T}$ & 1 \\
\hline & & & & & & & & 1 \\
\hline & 1 & & & & & & 1 & \\
\hline & 1 & 1 & 9 & 3 & 6 & 5 & 6 & 7 \\
\hline
\end{tabular}

Fig. 3. Conodont species, Markada Borehole. 
indices for late Viséan and early Namurian age strata (Rhodes et al. 1969, Higgins 1975 and Meischner 1970). The presence of Gnathodus homopunctatus indicates a Viséan age at least to a depth of $1297.60 \mathrm{~m}$ Gnathodus texanus and Gnathodus pseudosemiglaber which are present below the first appearance of Gnathodus homopunctatus have their oldest stratigraphic occurrence in the Scaliognathus anchoralis Zone, which is of late Tournaisian age (Lane, Sandberg \& Ziegler, 1980). Despite the low yield of conodonts we suspect the Tournaisian-Visean boundary to fall within the interval of Core 6.

\section{THE MARKADA BOREHOLE: (Fig. 3)}

Samples from Core 21 contained no conodonts. Only one horizon in Core 18 contained conodonts. Samples from the Markada Borehole at a depth of $3120.30 \mathrm{~m}$ contained two broken specimens of Neogondolella mombergensis. The specimens clearly exhibit the fairly broad platform features, which are rounded posteriorly. The platform forms a point at the anterior end and the carina is low. The presence of this species in Core 18 is indicative of a Middle Triassic age (Mosher, 1968). The genus was not recovered from any other sample. It represents the first record of Triassic conodonts from Syria.

Samples from the interval $3363.80 \mathrm{~m}-3436.40 \mathrm{~m}$ of Cores 19 and 20 are characterised by the presence of Gnathodus pseudosemiglaber. At depth $3362.60 \mathrm{~m}$, a single specimen of $G$. cuneiformis occurs together with a specimen of $G$. texanus. The sample from depth $3435.90 \mathrm{~m}$ produced two specimens of Apatognathus geminus together with Spathognathodus scitulus. This association indicates that at this level there is a shallow water facies (Austin, 1976). Gnathodus texanus occurs again at depths of $3436.40 \mathrm{~m}$ and $3429.85 \mathrm{~m}$.

The presence of Gnathods texanus, Gnathodus cuneiformis and Gnathodus pseudosemiglaber implies that the rocks present in Cores 19 and 20 of the Markada Borehole are of late Tournaisian-early Viséan age.

\section{THE JBISSA BOREHOLE: (Fig. 4)}

Only three samples from the Jbissa borehole at depths of $3869.40 \mathrm{~m}, 4147.80 \mathrm{~m}$ and $4178.90 \mathrm{~m}$ in Cores 1,3 and 4 yielded conodonts. Cores 2 and 5 did not yield any conodonts. The specimens recovered are mostly frag-

\begin{tabular}{|l|c|c|c|}
\hline \multicolumn{3}{|c|}{ JBISSA } & BOREHOLE \\
\cline { 2 - 4 } & Core 1 & Core 3 & Core 4 \\
\hline CONODON IN BOREHOLE Metres) & $3869 \cdot 40$ & 4147.80 & 4178.90 \\
\hline Gnathodus Cuneiformis & & & \\
Gnathodus pseudosemiglaber & & 3 & 6 \\
Lonchodina furnishi & & 1 & 2 \\
Fragments & 3 & 28 & 130 \\
\hline
\end{tabular}

Fig. 4. Conodont species, Jbissa Borehole. mentary, but a few are sufficiently well preserved for generic and specific identifications to be made. The species Gnathodus pseudosemiglaber and Gnathodus cuneiformis are recognised in Core 4 and Gnathodus pseudosemiglaber in Core 3, which implies an age close to the Tournaisian-Viséan boundary.

\section{THE ROUMYLAN BOREHOLE:}

All samples from the Roumylan Borehole were devoid of conodonts.

\section{REPOSITORY OF SPECIMENS}

The conodont specimens of this study are deposited at the Department of Geology, The University, Damascus.

\section{ACKNOWLEDGEMENTS}

Financial support and the granting of sabbatical leave by Damascus University, is gratefully acknowledged by Samira Husri. We appreciate the assistance offered by the Syrian Petroleum Company, which supplied the samples. We especially wish to thank Dr. N. Nabulssi, Dr. M. Mahfood and the geologists F. Sukarih and S. Nassri. The facilities provided by the University of Southampton are gratefully acknowledged.

\section{REFERENCES}

Austin, R. L. 1976. Evidence from Great Britian and Ireland concerning West European Dinantian conodont paleoecology. In Barnes, C. R. (Ed.), Conodont Paleoecology. Geol. Ass. Can., 15, 201-224.

Dubortret, L. 1932. Les formes structurales de la Syria et de Palestine, leur origine. C.r. Seances Acad Sci., 195, 66-68.

Higgins, A. C. 1975. Conodont-zonation of the late Viséanearly Westphalian strata of the south and central Pennines of northern England. Bull. Geol. Surv. G.B. London., 53, 90 pp. pls. 1-18.

Lane, R. H., Sandberg, C. A. \& Ziegler, W. 1980. Taxonomy and phylogeny of some Lower Carboniferous conodonts and preliminary standard post-Siphonodella zonation. Geologica et Palaeontologica, 14, 117-164, pls. 1-10.

Meischner, D. 1970. Conodonten-Chronologie des deutschen Karbons. Congrès Avanc Étud Stratigr. Carb. Sheffield, 1967. 111, 1167-1180.

Mosher, L. C. 1968. Triassic conodonts from Western North America and Europe and their correlation. J. Paleont., 42, 895-946, pls. 113-118.

Ponikarov, V. P. 1969. The geology of Syria. "Nedra" Leningrad (in Russian).

Rhodes, F. H. T., Austin, R. L. \& Druce, E. C. 1969. British Avonian (Carboniferous) conodont faunas, and their value in local and intercontinental correlation. Bull. Br. Mus. nat. Hist. (Geol), Supplement 5, 313 pp. 31 pls.

Stoppel, D. 1970. Die Fauna des Karbons vom Djebel Abd-elAziz (Nordost-Syrien) N. Jb. geol. Paläont. Abh., 135, 213 225 , pl. 29.

Weber, H. 1964. Ergebnisse erdölgeologischer Aufschlussarbeiten der DEA in Nordost Syrien. Erdöl und Khole, Erdgas, Petrochemie, 16.

Wolfart, R. 1967. Geologie von Syrien und Libanon. Gebrüder Borntraeger. Berlin, 326 pp.

Yankauskas, T. 1976. Stratigraphic Scheme of Paleozoic in Syria. Syrian Petroleum Company. Unpublished Report. 


\section{Explanation of Plate 1}

Figs. 1, 13, 15, 16. Gnathodus pseudosemiglaber Thompson \& Fellows Oral view of specimens Sy. 4, 31, 18, 20, 1, 13, sample M.K.20, 3428.95, ×54. 15, 16, sample SWB.6, 1297.60, ×66.

Figs. 2, 8, 9, 12. Gnathodus cuneiformis Mehl \& Thomas Oral view of specimens Sy. 29, 5, 21, 33. 2, sample M.K.20, 3429.85, SWB.1298, $\times 56$, sample SWB.6, 1297.80, $\times 72.12$, sample JB.4178.90, $\times 120$.

Figs. 3, 7. Gnathodus texanus Roundy 3, Lateral view of specimen Sy. 26, sample SWB.6, 1298.80, ×45. 7, Oral view of specimen Sy. 3, sample SWB.6, 1298.80, $\times 53$.

Figs. 4, 5, 14. Gnathodus girtyi girtyi Hass Oral view of specimens Sy. 8, 6, 2, sample SWB.6, 1296.80, 4, 5, × 50, 14, $\times 80$.

Fig. 6. Gnathodus symmutatus symmutatus Rhodes, Austin \& Druce Oral view of specimen Sy. 1, sample SWB.6, $1298.70, \times 68$.

Fig. 10. Gnathodus bilineatus Roundy Oral view of specimen Sy. 13, sample SWB.6, 1296.80, $\times 71$.

Fig. 11. Gnathodus homopunctatus Ziegler Oral view of specimen Sy. 17, sample SWB.6, 1297.60, $\times 92$.

Fig. 17. Spathognathodus scitulus Hinde Lateral view of specimen Sy. 12, sample M.K.20, 3435.90, $\times 53$.

Figs. 18a, b, 19. Neogondolella mombergensis Tatge 18a, 18b Oral and lateral view of specimen Sy. 14, $\times 63.19$, Lateral view of specimen Sy. 15, sample M.K. 18, 3120.30, $\times 80$.

Fig. 20. Gen. et sp. indeterminate Lateral view of specimen Sy. 16, sample M.K. 18, 3120.30, × 107 .

Fig. 21. Lonchodina furnishi Rexroad Lateral view of specimen Sy. 23, sample SWB.6, 1296.80, $\times 57$.

Fig. 22. Neoprioniodus scitulus Branson \& Mehl Lateral view of specimen Sy. 30, sample M.K. 20, 3436.40, $\times 53$.

Fig. 23. Lonchodina sp. Lateral view of specimen Sy. 19, sample SWB.6, 1297.60, $\times 65$.

Fig. 24. Ligonodina roundyi Hass Lateral view of specimen Sy. 22, sample SWB.6, 1297.60, $\times 67$.

Fig. 25. Euprioniodina microdentata (Ellison) Lateral view of specimen Sy. 24, sample SWB.6, 1297.60, $\times 53$.

Fig. 26. Hindeodella ibergensis Bischoff Lateral view of specimen Sy. 28, sample SWB.6, 1269.80, $\times 57$.

Fig. 27. Ozarkodina plana Huddle Lateral view of specimen Sy. 27, SWB.6, 1298.70, $\times 60$.

Fig. 28. Lonchodina furnishi Rexroad Lateral view of specimen Sy. 28, M.K. 20, 3436, $\times 80$.

Fig. 29. Lonchodina $S p$. A. Lateral view of specimen Sy. 32, M.K. 20, 3429, $\times 65$.

Fig. 30, 32. Apatognathus geminus Hinde Lateral view of specimens Sy. 9, 10, sample M.K. 20, 3435.90, $\times 53$.

Fig. 31. Apatognathus sp. Lateral view of specimen Sy. 11, sample M.K.20, 3435.90, $\times 53$.

Fig. 33. Neoprioniodus sp. Lateral view of specimen Sy. 7, sample M.K.20, 3436.40, $\times 53$. 


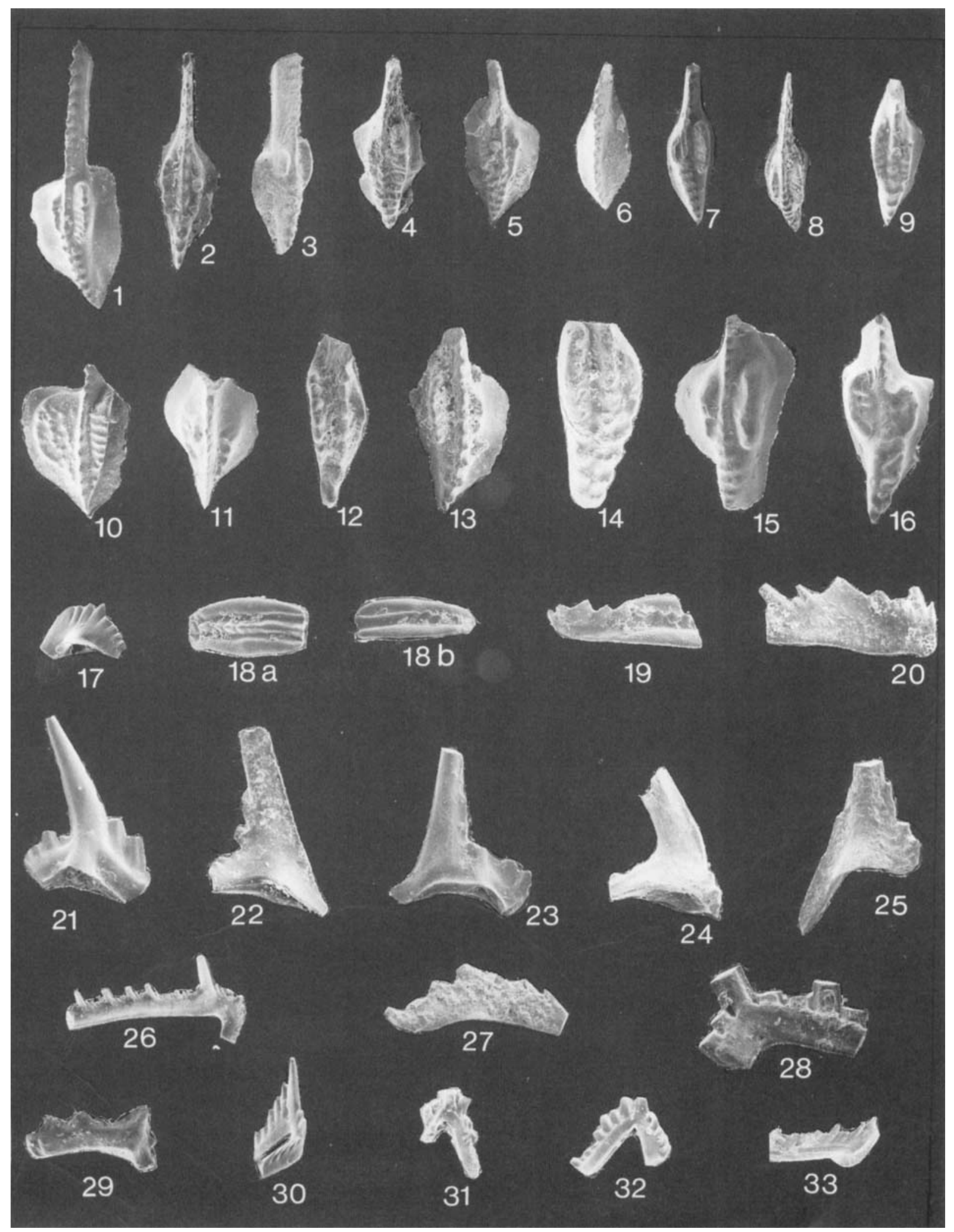

